\title{
The Development of Digital Television Broadcasting in Turkey
}

\section{Topcu 0. ${ }^{1}$}

\author{
${ }^{1}$ Özge TOPCU, Istanbul Aydın Üniversitesi, (Turkey ) \\ e-mail: ozget@stu.aydin.edu.tr
}

\begin{abstract}
With the effect of technological developments, mass media has become an indispensable element of social life. With this change, the speed of sharing of information is now becoming much easier with the increase of sharing. With the developments in television technology, television is able to be actively found and interacting with the television viewer, with the one-way communication structure being overcome. Along with the growing developments in television broadcasting, it is ensured that the directional message transmission is bidirectional. The interaction with which digital publishing has become a viewer also manifests itself in distance education programs that are being carried out with television. It has been observed that distance learners have an even beter learning or teaching position. With the developments in television broadcasting, the television monitor, now supported in digital broadcasting, can now buy the program as well as have information about a program. In this study; especially in the 1990s, is one of the topics of debate in digital publishing and development.
\end{abstract}

Keywords: digital television publishing, television publishing development, Turkey

\section{Introduction}

We face with the new concept of digital broadcasting that is especially used to reach radio and television broadcasts. In other words digital broadcasting; from writing to graphic, from display to sound is with the technological change of the contexs where all these concepts are generated, also creating another common language for their state of transfer. Transition from analogue system to digital system in broadcasting field, it appears to be a proccess that has been happening since the 1970s. This process is not independent of parallel developments in the field of communication and information technologies. Telecommunication, that had separate fields until this time, is the most important feature in this process, ending the boundaries between both information and broadcasting (Sümer, 2002: 2). Radio and television broadcasting, is made both privately and publicly, with two different approaches, but sometimes together. When we examine the developments in the world, in the United States, we see that radio and television broadcasts are made by private enterprises, while in Europe, until 1980, we can see that public broadcasting is the sole judge. One of the advantages of digital broadcasting in television broadcasting is the concept of interaction. With this concept, the television audience has left the passive audience, such as the old, and has now shifted to a more active state.

Communication is a concept that has always been neccasary throughout the ages for people to have understandability and understand each other. From the figures drawn on the walls of the cave to communication with smoke, communication is a concept that comes up in every case. With the invention of writing, communication has now reached a wider scope and this made people obliged to work in this area.

Later with the addition of audio and image, the methods of photo and sound recording have been developed. With the transmission of sound from one place to another place by electromagnetic 
waves, mass cominication was created and that was named as television. Many studies have been made on this device with the result of the television entering the communication world, it is possible to see them, and as we have seen in the studies, television has evolved till now. technology;

Williams mentioned of three general purposes that are originated from social order not

1. That the speed of development of technology depends on the balances found in both economic and political institutions,

2. That technology could possibly be used to cross national boundaries in culture and commerce, so the fact that the real situation is not really just,

3. That technology being unavoidable and unstoppable might be the result of openly and secretly marketing profits (Yengin, 1996: 66).

One of the results of the new technology is that the differences between communication media begin to increasingly becomes unclear. The forms of communication are no longer the same, as the computers, satellites become more important the borders will become more unclear. This revolution in communication technology has changed the boundaries of communication speed, and this change has also made it very difficult for people to grasp. Now with the internet now everything can be anywhere at any moment. Virtual reality removes the distinction between the individual and the computer. In this sense, virtual reality aims to measure the users' reaction by showing the user events that are not actually happening like they are. Reality has lost its meaning in the concept of giving reality to objects and consists of illusion entirely (Yengin, 1996: 67).

The developments in communication and its effects on the mass media have also caused changes in the social life and these were affected by changes. Therefore, this social structure is now defined as the information age with the influence of change. Along with the reflection of developments in digital technology, both to communication technology and to mass media, social life has been exposed to this change. This concept has been changed and the concept of information has left its place to the concept of the message with the new social context being called the information age. With sharing information, it made it easier for the production and distribution of this information. Information sharing in the information age has increased much more than the previous one and also became faster as much. A reason why for this is, is that duplex communication exists and there is a constructing that is made based on mass comminucation, and this brings along sharing information. Here, we will talk about the development of digitsl television broadcasting and its fetures,and its opportunities that are given to television viewer with its development will be shown.

\section{Digital Television Broadcasting}

Digital publishing; radio and television services, as well as access to these services. Satellite and internet technologies have played an important role in terms of digital broadcasting. Consequently;technology that is used in television nd telephones being adjusted to a context where computers connect with television sets is the substructure of the concept of digital broadcasting that we mentioned about.

Frequency; can be described as the value given to oscillation that electromagnetic waves have made in some time. As much as the frequency is infinite, because of the structure of communication frequency that is used in spectrums are as limited. The frequency reserved for radio and television broadcasting is always certain. For example; a frequency quentile that is used by a television channel can not be used by another channel (Sümer, 2002: 3). The frequencies were considered as public property and the question of the distribution of these goods among the people emerged. With that, two principles in the organization of radio and television systems appear. These are; public service and public purpose.

Publishing In Europe, benefits from the 'public service' where frequencies are used by the public sector whereas in the America institutions the publications are being carried out by the private 
sector, which is taking care of the benefits and interests of the public. Cable broadcasting system and satellite broadcasting system, it is possible to make these broadcasts at the same time in digital format. It is observed that a television broadcast made with digital broadcast technology is of better quality both in terms of sound and image as compared with the other analog broadcast system.

The advantages of the digital broadcasting of the television broadcasts and the cost of the cable broadcast system are very high and accordingly the wireless cable television system has been added in addition to these systems where the broadcasting of some broadcasting systems is not completely clear (Durmaz, 1999: 357). Cable broadcast was first made in the United States in 1994. With the developing technology, microwave links have been introduced and thus the number of channels being monitored by the cable has increased. Users have encountered new options. Cable Broadcasting is the method that establishes the most channel option. With the affect of information and communication technology of the 1990s, itshows us that the concept of information is now being used more and more intensely. As the digital definition it is actually " option " (Bonicci, 2003: 49). Options are given to the user and this gives the user the right to choose what they desire from the options. In everyday life too, digital technology is highly antagonistic. When you call it digital, only your mind, computer, phone, radio, refrigerator and many other things come out.

Digital Television Broadcasts communication standards: Digital television broadcast communications standards also include specifications for analog broadcasts. When we look at the analog broadcasting standards, NTSC, PAL and SECAM appears. If we look at the specifications of these standards;

Table: 1. Communication Standarts

\begin{tabular}{|c|c|c|c|}
\hline $\begin{array}{l}\text { NTSC (The National } \\
\text { Television Systems } \\
\text { Comitee ) }\end{array}$ & $\begin{array}{c}\text { It is currently used } \\
\text { in America and } \\
\text { Japan. }\end{array}$ & & \\
\hline $\begin{array}{l}\text { SECAM (Sequental } \\
\text { Color With Memory ) }\end{array}$ & $\begin{array}{l}\text { It was developed } \\
\text { by France. }\end{array}$ & $\begin{array}{l}\text { It is used in } 20 \\
\text { Eastern } \\
\text { European } \\
\text { countries except } \\
\text { France. }\end{array}$ & $\begin{array}{c}\text { It has higher resolution } \\
\text { than NTSC. }\end{array}$ \\
\hline $\begin{array}{c}\text { PAL ( Phase Alternate } \\
\text { Line) }\end{array}$ & $\begin{array}{l}\text { Developed in } \\
\text { Germany }\end{array}$ & $\begin{array}{l}\text { It is used in a } \\
\text { total of } 36 \\
\text { countries, mostly } \\
\text { of western } \\
\text { European } \\
\text { countries. }\end{array}$ & $\begin{array}{l}\text { The color is } \\
\text { superimposed over the } \\
\text { NTSC system. }\end{array}$ \\
\hline
\end{tabular}

(Reference: İspir, 2008: 71)

PAL, SELAM and NTSC standards emerged after grouping that was seen in some countries. When we look at digital publishing, we see that there are basically three different systems. We can list these publishing standards as follows; ATSC(Advanced Television Systems Comitee) (Collins, 2001: 3). SDB( Integrated Services Digital Broadcasting), DVB( Digital Video Broadcasting) (Hart, 2004: 181). With the digital publising in 1990s, we can say that digital publishing is the last ring of development in communication, with the production of broadcasting and the transmission at the same time. With the ongoing debatesi in America and Europe about the future of publishing, digital broadcasting is at the center of those subjects. With digital broadcasting, the television has left the situation as a monitored device and has become a used device. With digital technology, computer and internet operations can now be carried out from the television screen. With the telecommunication infrastructure, data exchange with the other party is now possible. It is now said that publishing becomes interactive. 
The spread of digitalization, which is one of the foundations of new technology, and the rapid adoption of this concept among the individuals are among the factors which cause the social structure to change and to be defined as the information age. Rogers' theory of "diffusion of innovations" in this direction is also forming the theoretical basis for the rapid adoption and expansion of this innovation by the society. According to Rogers; the concept of dissemination of innovations is the spread of new ideas in the social system together with communication channels for both social change and social development (Geray, 2003: 182 , Erdoğan ve Alemdar 2002: 456). This point is also a bit of digital broadcasting and how this concept emerged, let's talk about its advantages and disadvantages.

\section{Digital Broadcasting}

Since the invention of televisionit has continued to maintain its influence over the world until today, and it has always been renewed according to the requirements of technology. (Şahin, 1991: 17). After the industry, information is now the most important source for society, and communication is the most important infrastructure. The first television studies in turkey started with the aim of getting the students of the High Frequency Technique Science School affiliated to Istanbul Technical University with practical training. With this initiative, without the aim of being able to go on a regular basis for the firstly, it was aimed to establish only the system (Yengin, 1994: 67). When it came to the 20th century from the 19th century, important changes happened along with the development of technology. With the invention of television there has been a significant change in mass media. Transnational television broadcasts can reach a wider audience, along with this television broadcasting changed comminication' layout to a new one (Yengin, 1994: 20). Smart TVs now face antagonism in every home and this is an important example. One of the developments in television broadcasting is that the digital broadcasting system replaces analog broadcasting (Bağcl, 2016: 3). The developments in communication in the 1980s included the transmission of radio and television devices (cable television, satellite broadcasting, paying broadcasting) to the audience. In the 1990s, digital technology emerged as a digital technology, and the telecommunication infrastructure used to transfer telephony or data was used for digital broadcasting (Çaplı, 2001: 51).

Electronic systems are divided into two parts as 'analog' and 'numerical' (Kırık, 2010: 29). Analogue television has now left its place to digital broadcasting technology (Aydın, 2000: 11). The concept of analog television is described as a system that uses ever-changing signals. the value between two frequencies in the analog broadcasting being infinite One of the important features.

Initially, the electronic circuits were made analog, and then these systems started to digitize. The reason fort hat was digital circuits being more reliable than analogue systems (Morgül, 2011: 136).

Broadcasters deliver these digital services to us in 5 different contexts. It is possible to list them as "satellite, terrestrial, cable, network, mobile". In addition to the technological improvements, providing interactive services in television and radio broadcasts were developed with digital television. Until 1990, it is difficult to say that there is digital television in houses. With the developments in the past, television broadcasting has now moved to a different dimension. Thanks to digital broadcasts, the audience is now in a state of freedom against television. It can reach the desired content for a certain fee when it wants, and the desired information can be easily accessed from the television screen (Seker, 2009: 14).

Digital television is defined as 'Digital Television Broadcasting' (DTVB) or 'Digital Video Broadcasting' (DVB). These definitions mean that the digitized audio and video signals are transmitted as data signals (Eraslan, 2006: 31). Digital image and sound was started to be used in radio and television broadcast centers in the 1990s. Digital television started to make its first broadcasts in 1994. And since 2000, all satellite broadcasts have become digital and these developments have been followed by cable TV. 


\section{Advantages and Disadvantages:}

When we look at the advantages of digital publishing, we have a long list of opposition.

- Service providers can transfer many programs with a single data channel. With this feature, digital televisions being beter at using better data rates was clear.

- It has a superior sound and image quality compared to analogue spring.

- It is possible that the image on the TV can be recorded, stopped and replayed at any time.

- Interactive applications have begun to be used.

- Language options and subtitles position of the monitored channel were started to be supported (Lyngsat, 2013).

Besides;

- In analogue system even if there is a malfunction the signal can be monitored, when the digital broadcast can not be watched in any negative situation. Because of that, all the negative situations that could happen should be evaluated with the signal that is sent by the transmitter at the same time an analog data is transforming to a digital data (Pehlivanlı, 2010).

\section{Image Formats in Digital Television Broadcasting}

In today's broadcast, image resolution is defined as 'high defi- nition HD' and 'standard defi- nition SD' according to features such as screening system and frame rate (Kala, 2012: 21).

Table 2. Image formats

\begin{tabular}{|c|c|}
\hline HDTV & SDTV \\
\hline $\begin{array}{l}\text { With the use of many more pixels, it also } \\
\text { provides more detailed viewers in terms of } \\
\text { image. }\end{array}$ & $\begin{array}{l}\text { The most common PAL and NTSC formats } \\
\text { transfer video to a quality defined standard. }\end{array}$ \\
\hline $\begin{array}{l}\text { It is clearer and so lighter in terms of image } \\
\text { dimensions (Simpson, 2008: 65). }\end{array}$ & $\begin{array}{c}\text { It gives richer color and better image } \\
\text { service. }\end{array}$ \\
\hline $\begin{array}{l}\text { From a distance, it ensures that all details } \\
\text { can be perceived (Sankur, 1998: 23). }\end{array}$ & $\begin{array}{c}\text { For years as a viewer, the viewer has } \\
\text { delivered a quality service but has been } \\
\text { adversely affected by the deterioration in } \\
\text { the image (Ibrahim, 2007: 59). }\end{array}$ \\
\hline $\begin{array}{l}\text { Japan has come to be used in all of Europe } \\
\text { and Turkey except the United States. }\end{array}$ & It is based on digital technology. \\
\hline It is based on digital technology & \\
\hline $\begin{array}{l}\text { In addition to the satellite receivers of the } \\
\text { viewer watching the high-definition } \\
\text { television channel, the televisions must also } \\
\text { be HD compatible. }\end{array}$ & \\
\hline
\end{tabular}

(Reference: Morgül, 2011: 159)

Digital technology in the field of television started to show itself in 1980s. Digital technology is a complicated and as much expensive structure. So in the first place, because of that it was done only for recording devices. With the advent of technological developments in the 1990s, many new features of television have been added. Digital technology has changed the construction of publishing. Different channels in different constructions emerged with the internet becoming more common and speed of accessing information increasing. Developments in technology in the 19th century underlied the basis of the new media context. In this regard, television with multimedia, kept up with the internet. 
Television is standardly defined as digital television that offers the viewer richer color. Both of the formats depend on digital technology. Standard television was affected negatively because of the image distortions, and has lost its importance compared to its old importance. New generation TVs are catching the attention of television broadcasters and television producers. We are seeing that the defined technology is now used in the TVs in Turkey and the workings on this subject are spreading day by day. HDTV is defined as the most important innovation for television technology. Eventhough the standardization of the HDTV was a problem in the beginning, with the order of solution, satellite broadcasting was stared to be made with other systems. With this advancement in television technology, audiences are now enjoying a high quality viewing experience both visually and audibly.

\section{Digital Publishing in Turkey}

With the start of digital television broadcasting in Turkey by platforms on satellite in 1999, spreading rapidly with different transmission areas increasing day by day. In the information age, individuals who are constantly communicating with each other in an intensive communication framework based on technology, will become a global cultural product and thus create a global society (Binark ve kılıçbay, 2005: 19). Digital publishing in Turkey was emerged in 1999 with the start of " digital platform " broadcasts via satellite. The digital publishing agenda has been a problem between the launch of platforms for the first time and the RTÜK and publishing platforms, and the agenda has begun to shape gradually. Therewithal there has been a competition between respective institutions for the display of some TV programs, especially for the screening of football matches. There has been no clear statement of what the digital publishing is during this period, how this publication can be particularly influential in Turkey and how it will be shaped.

In this direction, McLuhan shows us that the electronic media, brings people together and in some way similarizes with the concept of "global village". McLuhan says that in the global village, everything is the same, and the time and space are left with the influence of the electronic media ( Altay, 2003 : 11).

When we consider nowadays we can see that we are actually living in the middle of the age of digital technology. Because a vehicle with digital technology in many areas of our daily lives (workplace, home, car, etc.) is always at hand. The concept of new media is coming up with the technology that develops at this point. The concept of new media; has emerged when mass media come together with new technology and with this concept, new features was added to the features that mass media had. Can now be communicated anywhere at any time, anywhere, without the limitation of time or space, and two-way communication is among the possibilities offered by the new media. Actually new media; is defining an unlimited number of communication channels that an individual has selected with the content they want (Webster ve Phalen, $1997: 100$ ). With this information, it can be said that the new media includes mass media which are connected to digital technology. According to Marshall, these two concepts named traditional media and new media, include technologies that are connected to each other and change only as the form (Marshall, $2004: 2$ ). When we look at the output of digital electronic systems, we can see that in 1950, the first tube computer came out with the invention. This technology takes place in our daily lives in the 1970s. Since these dates, the renewed technology appears in many contexts and spreads rapidly.

Despite the constant change of technology, television still has the same popularity. When we look at it, we find television antennas almost everywhere in the world, especially in poor regions. As it can be understood from this, it is arguably the most popular and fast-spreading vehicle in television broadcasting technology (Fidler, 1997 : 195).

When the development of television broadcasting is examined, there are three periods of anticipation (Walker \& Ferguson, 1998: 12) 
1.First generation television broadcasting: It is defined as the process which started from the 1920 s to the mid-1970s, when the last 20 years in publishing are called the golden age.

2.Second generation television broadcasting: This process shows the beginning of cable television broadcasting. There was also an increase in the number of television stations in this period.

3.Third generation television broadcasting: The period in which digitalization has become increasingly widespread, that is, the process that began in the 1990s and still continues.

Television broadcasting lived its golden age especially in the third generation (Fidler, 1997 :196 ). 1900s are the years that broadcasting was started to meet the audience. Digital television broadcasting offers different levels of qualification to the viewer. Standard definition television (SDTV), extended definition television (EDTV), and high definition television (HDTV) (Schiller, 2003 : 193).

If we look at the definitions of these systems; SDTV (standard definition): The system has a lower image resolution than the HDTV system. The viewer is now starting to move further into widescreen programming. SDTV standards have also been brought into line with 16.9 frame rates (Poynton, 2003 : 99). EDTV: Has a quality between a standard definition television system and a high definition television and has been developed as a result of the increasing number of channels through direct broadcast broadcast satellites (Rigel, 1991: 39). HDTV: It has a higher resolution compared to other systems. The high image quality it has is 6 times higher than other broadcasts available (Dupagne, $1999: 37$ ). Is defined as the last revolution in television technology as compared to other systems.

When we look at IPTV as another broadcasting field in Turkey's television broadcasting; It is internet based and offers a secure service to its users. IPTV has gained importance in 2000's years, and in Turkey we can see that it has gained importance since 2007. From that date to today IPTV technology has developed considerably and has become recognized by the target audience. A lot of studies had been done in November 2007 "IPTV research and development center" and Alcatel Teletaş "IPTV support center" about the development of IPTV's architecture, software systems and products within the scope of these studies ( Aytekin; Şahin \& Düvenci, 2008: 5).

At this point we can talk about another channel that emerged differently from IPTV and Web TV: Over The Top (OTT): Overthe Top, is defined as being over something. OTT is essentially a television service offered over the Internet. Is a term used on the internet for audio, video, publishing and technology. Which is being sent via internet depending on the flow technology. OTT is different than IPTV and Web TV. Web tv is a television that can be watched on the computer without subscription. And IPTV solves through a special box and can be viewed from the television screen. IPTV is an application that requires a subscription. Thanks to OTT, the user can now access to the TV programs that was broadcasted previously. OTT, IPTV and web TV. The user can access previously published programs from the television screen instead of reaching the computer. OTT, offers us easy achievement to this archive.

Nowadays there is a growing interest to the Internet series that are no more than sixty minutes long, do not exceed thirteen episodes in a season, and attract people's attention. These series confront us with a different style from the traditional one, and they especially care about the likes of the new generation and they wink at the new habits of the users. The reason why Turkish viewers met internet series is foreign series. It is a foreign sequence that starts to meet with the internet trailers. People have had the chance to watch foreign films they want one by one on the internet through foreign series sites and this became a habit for them. At home, at work, at school, in short, the idea of being able to see and hear a sequence everywhere where internet connection was available was very 
attractive to people. Channels like Digitürk, D-smart, cable TV, CNBC-E made the foreign series adventure interesting and the new generation had a different set of viewing habits.

With Netflix entering the country officially, the of BluTV and Puhutv entering to the market and the spread of the series broadcasted on YouTube from the ear to the ear have made it an alternative market for traditional market.

4K Technology: $4 \mathrm{~K}$ is presented to us as the latest popular display and video resolution. At the $4 \mathrm{~K}$ resolution, the letter " $\mathrm{k}$ " represents the thousand digits and is used in abbreviated form. $4 \mathrm{~K}$ gives the viewer more detail than other TVs. The number of pixels is higher than the others, and the picture quality is also higher. It is a resolution format commonly used in movies and games. Representing $4 \mathrm{~K}$, $720 \mathrm{p}$ and $1080 \mathrm{p}$ vertical numbers that accommodate 4000 pixels horizontally. We can define $4 \mathrm{~K}$ as ultra hd, which is the upgraded version of the hd concept we are using. Goal; is to increase the progress of technology in Turkey and providing support to television producers to increase 4K TV sales. We can say that it is good but also costly for Turkey.

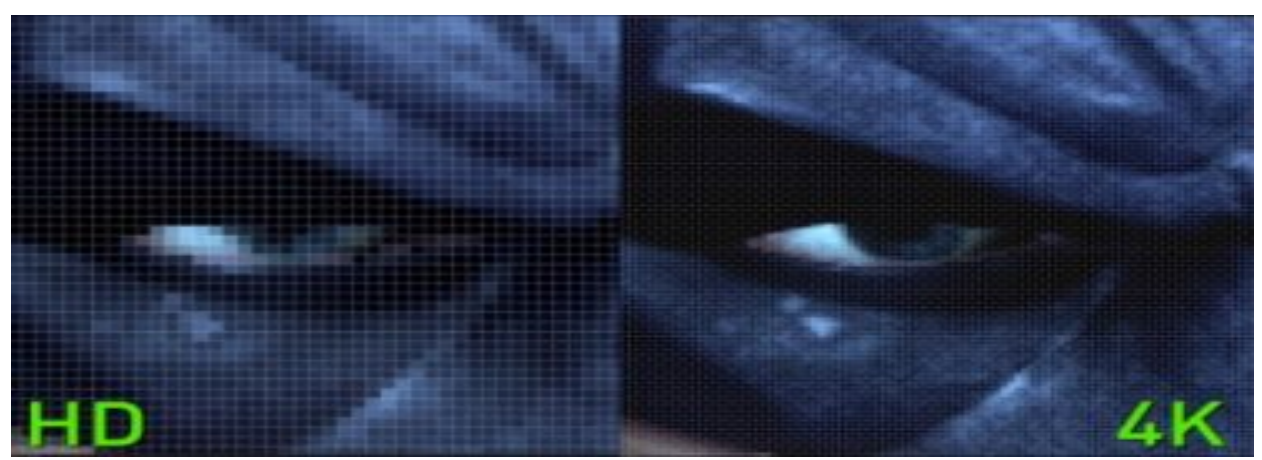

Image 1. 4K Broadcasting

(Reference: https://www.teknolugat.com/herseyiyle-4k-teknolojisi).

TRT that makes $4 \mathrm{~K}$ broadcasting, finished its test publication in 2015 , and met with the audience in 2016. Digiturk introduced $4 \mathrm{~K}$ it uses as " clearer image, bigger excitement " and started to broadcasing life. To view these channels, the user must have a TV with $4 \mathrm{~K}$ ultra-Hd resolution and the satellite receiver must be $4 \mathrm{~K}$ compatible.

\section{An example of digital publishing: Digiturk Play}

Digiturk play is a package that enables the audience to watch channels without a dish antenna via the internet.

Table 3. Digiturk Play

\begin{tabular}{|c|c|c|}
\hline Super League Packs & Sports Extra Pack & Entertainment Package \\
\hline $\begin{array}{c}\text { Buy Super League } \\
\text { matches, next to TFF 1st } \\
\text { League matches }\end{array}$ & $\begin{array}{c}\text { Premier League, LaLiga, } \\
\text { TFF 1st League, } \\
\text { Euroleague package } \\
\text { includes. }\end{array}$ & $\begin{array}{c}\text { With more than 1000 domestic } \\
\text { and foreign HD movies, } \\
\text { hundreds of episodes of } \\
\text { domestic and foreign series, } \\
\text { more than 60 live TV channels } \\
\text { with subtitle and dubbing options }\end{array}$ \\
\hline
\end{tabular}

(Reference: https://www.digiturkplay.com.tr/) 
Digitürk play, has emerged with the slogan of " smart TV at home, on the computer, on the road, tablet on vacation ". We can watch the channels on computers, tablets, smartphones and televisions (in the IPTV box). Digiturk play offers us the opportunity to watch more than 60 live TV channels in the place we want. It is possible to watch live sports events including super league, hundreds of movies and series, live television channels on web, on cell, on tablets and on smart TV. Without setup, at any time everyone can become a member and can cancel membership.

Digiturk play offers membership login for users, so that digiturk broadcasts can be easily viewed on the internet without using a digital receiver. When Digiturk was previously introducing this service to users with the name of digiturk web tv, this service was offered free of charge to users who also had digiturk service at home and also it was closed to the new memberships, Shortly after, the user had the chance to get a digiturk web tv membership. In the early days of broadcasts, the image quality was poor and users were experiencing frequent problems. After the site was completely renovated and the name was " digitürk play ". Digiturk was offered a membership subscription called Premium membership with the addition of other football leagues, basketball leagues, series, films and live television options. Price began to rise when digiturk play became popular.

With the digiturk play application, the user can select hundreds of local and foreign films, documentaries, sports and serials by selecting the "Select and watch" category. In addition to premium membership, the user can use the Premier League, LaLiga and Euro league packages along with the cinema package. Users can also access live watching and replaying of the programs they want as a member of the desired pager through the Digiturk play website. Considering all the features of digiturk play application with pros and cons a table like below appears.

Table 4. Digiturk Play Application Pros and Cons

\begin{tabular}{|c|c|}
\hline \multicolumn{1}{|c|}{ CONS } & PROS \\
\hline $\begin{array}{c}\text { It is possible to interrupt the broadcast } \\
\text { at any time }\end{array}$ & $\begin{array}{c}\text { Broadcasts can be viewed over the } \\
\text { internet without the need for any } \\
\text { setup. }\end{array}$ \\
$\qquad \begin{array}{c}\text { - Live match broadcasts can come } \\
\text { back for } 30 \text { seconds and television } \\
\text { broadcasts can go back for 1 minute } \\
\text { The live support system sometimes } \\
\text { fails to provide adequate service }\end{array}$ & $\begin{array}{c}\text { With renewed packages, you can } \\
\text { now watch broadcasts with Smart } \\
\text { TV. }\end{array}$ \\
$\begin{array}{c}\text { Given the quality and availability of the } \\
\text { service provided, the annual fee may } \\
\text { be too high for some users. }\end{array}$ & $\begin{array}{c}\text { All belN Sports channels } \\
\text { wroadcasting match broadcasts can } \\
\text { be watched continuously and } \\
\text { continuously }\end{array}$ \\
\hline
\end{tabular}

(Reference: https://www.salihkunduz.net/artilariyla-eksileriyle-digiturk-play/)

Digiturk play has disadvantage features along with the advantages. One of the negative features is interruption situation of the broadcasts and sometimes with sufficient service being not provided, but when we look at the positive features the most outstanding one is allowing the user to reach whichever channel they want and whatever they want to to watch. The channel offers different options and the user can instantly access the file from the match up to other programs. Of course, while the user has the option of watching the channel he wants among these options, it is quite uncomfortable to encounter such a situation that broadcasts are interrupted.

This may even cause them to lose the user. When we put this negativity aside, it encourages many people to become members of the site with the opportunities that are offered. 


\section{Results}

Wanting to have instant access to the information in many content increases day by day. We know there will be no communication without information. In the late 20th century, significant developments in the field of technology have been made. Television and people are now under more control than before. So now knowledge and concept are presented to us as a force. The need for communication, which is getting bigger and bigger every day, enables researches related to this field to be made and new and different systems can be created. Private TVs that have been embraced by society and became a phenomenon, entering to our houses, is an inevitable ending and when TVs are having unfair competition with them, it increases its profits as much day by day. So they have a negative social influence because they do not comply with any of the rules that must be followed in publications. People are now confronted with a communication bombardier, and we can say that television is one of the most effective weapons to direct people., Now people are watching On TV events that happened for the purpose of entertainment. The facts are pushed to the background, and the viewers can not face with the facts because they are in its spell. As a result of that, the viewer now confuses the imagination with the reality, becomes lonely, and is now under the influence of the magic of the screen. Because television is an important force in influencing the influence of the masses, the political struggle also manifests itself through this power and is an effective program tool. The principle of neutrality in television broadcasting has always been important. This principle applies to all programs. While this principle is generally discussed for newsletters, it is ignored for other programs. But this must be implemented in all publications. Because the viewer accepts the messages on the television screen without questioning whether they are correct or not. However when we are taking about digital broadcasting the first thing that comes to mind is display and sound transmission, actually, it is in very much larger area than analog system. The developments that are happening as digital publishing have a great imortance to the transformation of television broadcasting. Digital platforms were established in turkey in 1999 and since that date, competition has started between media groups to date. This competition has hampered the implementation of plans for digital platforms. Among these platforms, one of the self-savy ones has become "digiturk". Therefore, it is difficult for Turkey to be able to foresee the future of publishing, especially with a single institution. With digital broadcasting, everyone is now equal. Anyone who owns a computer or a phone can access to the information, the anytime and anywhere they want. Digital publishing is defined as an "opportunity paradise". If you can come to thousands of people in a social media campaign today, we can say where it ends.

\section{References}

[1] Rigel, N.E. (1999). Elektronik Rönesans, İstanbul : Der yayınları

[2] Durmaz, A. (1999). Profesyonel Televizyon Yapım ve Yayın Teknolojileri, Eskişehir Anadolu Üniversitesi Eğt.Sağ.ve Bil. Araş. Çalışmaları Vakfı, Yayın No : 147

[3] Bonicci, S. (2003). Which Channel is That On ? Programme Guides, U.K.,

[4] Collins, G.W. ( 2001). Fundamentals of Digital Television Transmission, USA

[5] Hart, J.A. (2004). Technology, Television and Competition, Cambridge

[6] Geray, H. (2003). İletişim ve Teknoloji , Ankara : Ütopya yayınları

[7] Erdoğan, İ. , Alemdar, K. (2002). Öteki Kuram, Ankara : Erk yayınları

[8] Altay, D. (2003). Kadife Karanlık, İstanbul : Su yayınları

[9] Marshall, D. (2004). New Media Culture, NY : Oxford Uni.

[10] Fidler, R. (1997). Understanding New Media, California

[11] Aydın, S. (2000). Televizyon Terimleri Sözlüğü, İstanbul : Türkmen Kitabevi

[12] Çaplı, B. (2001). Televizyon ve Siyasal Sistem, Ankara : İmge Kitabevi

[13] Morgül, A. (2011). Sayısal Televizyon Tekniği, İstanbul : Papatya Yayıncılık

[14] Şeker, T. (2009). Teknoloji ve Televizyon 
[15] Eraslan, M. (2006). Genişbant Bilgisayar Ağları Üzerinden Sayısal Televizyon Yayıncılığı, Muğla Üniversitesi Fen Bilimleri Enstitüsü İstatistik ve Bilgisayar Bilimleri Anabilimdalı, Muğla

[16] Kala, D. (2012). IPTV Teknolojisinin Geleceği ve Türkiye Pazarındaki Yeri, Haliç Üniversitesi Fen Bilimleri Enstitüsü Bilgisayar Mühendisliği Anabilim Dalı Yönetim Bilişim Sistemleri Programı, İstanbul

[17] Simpson, W. (2008). Video Over IP: IPTV,Internet Video, A Complete Guide to Understanding the Technology, Elsevier

[18] İbrahim, K.F. (2007). Newnes Guide to Television and Video Technology : The Guide

[19] https://www.salihkunduz.net/artilariyla-eksileriyle-digiturk-play/

[20] Bağcı, C. (2006). Türkiye'de Sayısal Televizyon Yayıncılığının Sektörel Görünümü ve Yönelimleri , Kayseri

[21] https://www.teknolugat.com/herseyiyle-4k-teknolojisi/

[22] Yengin, H. (1994). Ekranın Büyüsü, İstanbul: Der yayınları.

[23] Şahin, H. (1991). Yeni İletişim Ortamı Demokrasi ve Basın Özgürlüğü, Basın Konseyi Bilimsel Araştırması, İstanbul

[24] Yengin, H. (1996). Medyanın Dili, İstanbul : Der yayınları 